\title{
Memória e cerimônia nos palácios assírios (I milênio A.E.C.): um estudo de uma sala do palácio sudoeste de Nínive
}

\author{
Memory and ceremony at the Assyrian Royal \\ Palaces (First Millennium BCE): a study of a \\ room of the Southwest Palace of Nineveh
}

\section{Memoria y ceremonia en los palacios asirios (Primer Milenio a.n.e.): un estudio de un recinto en el palacio suroeste de Nínive}

\author{
Leandro Penna Ranieri* \\ Submetido em: 30-6-2021 \\ Aceito em: 18-8-2021
* Universidade de São Paulo Pós-doutorando em História Antiga
E-mail: ranierileandro@usp.br

\begin{abstract}
RESUMO
O objetivo deste artigo é propor a noção de "cerimônia da memória" como uma das funções dos espaços palacianos da Assíria. Conta-se com uma análise de uma sala do palácio sudoeste de Nínive, denominada 36, e de seus relevos parietais esculpidos. Cerimônia da memória não está estritamente associada a um atributo elaborado e expresso na documentação visual, mas é uma prática de registro de tipo memorial num espaço cerimonial, que é similar à prática de elaboração das inscrições reais, ambas voltadas à comunidade palaciana no presente e para o futuro.

Palavras-chave: Mesopotâmia; Assíria; relevos palacianos; memória.
\end{abstract}

\section{ABSTRACT}

The aim of this article is to propose the notion of "ceremony of memory" as one of the functions of the palace spaces of Assyria. We focus our analysis on a room of the southwest palace of Nineveh (room 36) and on its carved wall reliefs. Ceremony of memory is not strictly associated with an elaborated and expressed attribute into the visual sources, but it is a memorial-type recording practice in a ceremonial space, which is similar to the practice of elaborating royal inscriptions, both aimed at the palace community in the present and for the future.

Keywords: Mesopotamia; Assyria; palace reliefs; memory.

\section{RESUMEN}

El objetivo de este artículo es proponer la noción de "ceremonia de memoria" como una de las funciones de los espacios de los palacios de Asiria. Hacemos un análisis de un recinto (36) del palacio suroeste de Nínive y de sus relieves parietales. La ceremonia de la memoria no está estrictamente asociada con un atributo elaborado y expresado en las fuentes visuales, más es una especie de práctica de registro memorial en un espacio ceremonial, que es similar a la práctica de preparar inscripciones reales, siendo ambas dirigidas a la comunidad del palacio, en el presente y para el futuro.

Palabras clave: Mesopotamia; Asiria; relieves; memoria. 


\section{Introdução*}

Nosso objetivo neste artigo é propor a noção de "cerimônia da memória" como uma das funções dos espaços palacianos da Assíria. Para isso, conta-se com um estudo de caso pautado na análise de uma das salas do palácio sudoeste de Nínive: a sala denominada 36, com seus relevos parietais esculpidos. Esses relevos trazem uma narrativa visual e sequencial de um episódio da terceira campanha do rei Senaqueribe (704-681 A.E.C.), em Lachish, no fim do séc. VIII A.E.C. Nossa análise considera as características do recinto e a sua localização espacial no setor do palácio, ao lado das imagens e da iconografia da guerra e violência nos relevos.

Os palácios mesopotâmicos, mormente os assírios no I milênio A.E.C., podem ser definidos como o centro de poder governamental dentro de uma cidade-capital (STONE, 2000). Além de tornarem-se o espaço físico da concentração de poder, a conexão do divino com o soberano, que era designado e legitimado pelo deus patrono assírio, Assur, incorpora a dimensão religiosa à casa da realeza, onde habitava a família real e sua corte. O palácio também concentrava um espaço cerimonial, no sentido de haver uma corte, regras de conduta e o exercício de funções e celebrações específicas, como, por exemplo, as visitas de delegações estrangeiras e banquetes. Além disso, nos palácios, os reis e rainhas eram enterrados. Por fim, era um centro de produção de textos, de onde partiam as cartas oficiais e os tratados (VERDERAME, 2014; GROß; KERTAI, 2019), onde se materializavam as inscrições reais (RUSSELL, 1999) e onde se produziam e acumulavam, especialmente no contexto do I milênio A.E.C., a produção do "conhecimento cuneiforme" da tradição mesopotâmica (RADNER; ROBSON, 2011).

Além desses elementos, as paredes das salas dos palácios assírios são conhecidas pela presença de relevos esculpidos, com imagens de cenas de guerra, caçadas a animais, construção e celebrações. A escultura em relevo em placas de pedra se concentra no período de desenvolvimento imperial da Assíria, entre os séculos IX e VII A.E.C., e começa a partir do reinado de Assurnasirpal II (883-859) em seu palácio em Nimrud (Kalhu). Posteriormente, entre os séculos VIII e VII A.E.C., sabemos dos reis da chamada

* Este artigo foi elaborado durante meu estágio pós-doutoral junto ao Departamento de História da Faculdade de Filosofia, Letras e Ciências Humanas (FFLCH) da Universidade de São Paulo (USP), que contou com bolsa da Fundação de Amparo à Pesquisa do Estado de São Paulo (FAPESP, processo $n^{\circ}$ 18/13540-7). Agradeço a Anita Fattori pela leitura crítica de uma das versões do manuscrito e a Pedro Paulo Melara pelo auxílio na edição das imagens. Agradeço também aos organizadores desse dossiê, Prof. ${ }^{a}$ Dr. ${ }^{a}$ Katia Maria Paim Pozzer e Prof. Dr. João Batista Ribeiro Santos, pelo convite e pela revisão e edição do manuscrito. 
dinastia sargônida que fizeram uso dos relevos parietais em seus palácios em outras importantes capitais assírias, como Sargão II (721-705), em Dur-Sharrukin (atual Khorsabad), Senaqueribe e Assurbanipal II (668-631), em Nínive (atual Mosul).

A história dos estudos sobre os relevos palacianos assírios tendeu inicialmente a tratar esses objetos, em grande parte representando cenas de guerra e violência, como objetos com objetivos propagandísticos e de intimidação pelo terror. O debate sobre tal questão, apresentado na sequência deste artigo, ainda deixa traços na literatura. Nos últimos 20 anos, a revisão desse teor propagandístico incorporou novas interpretações sobre os espaços palacianos, como é o caso do aspecto cerimonial, o que implica a realização de rituais específicos e enfatiza os usos múltiplos dos recintos e setores da construção e as performances num ambiente sensorialmente programado (BARJAMOVIC, 2011; WINTER, 2013; KERTAI, 2015; PORTUESE, 2019). É a partir dessas novas considerações sobre os espaços e os relevos palacianos que propomos a noção de cerimônia da memória.

A partir da análise da sala 36 e das imagens dos relevos de suas paredes, em comunhão com os aspectos espaciais de seu setor do palácio, propomos a noção de cerimônia da memória no sentido de a sala 36 ter sido um lugar de dedicação e uso específicos e ritualizados. Como veremos, o fato de os relevos serem objetos com acesso restrito, num ambiente com baixa acessibilidade, contribui para a sua consideração como um componente cerimonial. Além disso, acreditamos que o aspecto cerimonial pode dar enquadramento à memória, que contempla o conteúdo temático e iconográfico dos relevos, sobretudo a guerra e a violência. Destaca-se que cerimônia da memória não está associada a um atributo expresso na documentação visual, mas refere-se a uma prática de registro de tipo memorial para o presente (àqueles que viviam no palácio) e para o futuro (aos reis e cortes vindouros). A nosso ver, tal aspecto memorialístico é similar à prática de elaboração das inscrições reais, que celebravam os feitos dos soberanos em atuação e preservavam esses registros às gerações futuras. Não é novidade na literatura a complementariedade de conteúdo e função entre fontes textuais e imagéticas, que inclusive nos relevos palacianos costumam compartilhar do mesmo suporte material. No entanto, sob a chave de uma cerimônia da memória, registrar em texto e em imagem pode obedecer não só ao mesmo princípio celebratório, mas também pode apresentar as características de um mesmo processo memorialístico e cerimonial. 


\section{Os relevos palacianos funcionavam como propaganda?}

A história dos estudos sobre os relevos palacianos foi marcada por uma perspectiva que os tratava como uma fonte com propósitos propagandísticos. O uso da noção de propaganda atribuída à função potencial dos relevos pode ser representado por um breve debate, já com pelo menos três décadas, a partir das contribuições de Winter (1981) e Bachelot (1991).

Winter (1981, p. 2-3) declara sua abordagem baseada nas análises de mídias visuais da época de sua publicação, que contam com as noções de narrativa-história e narrativa visual, ${ }^{1}$ ambas contemplando uma forma de leitura daquilo que é representado nos relevos como uma realidade histórica registrada. A abordagem de Winter inovou o estudo das imagens dos relevos palacianos, alterando permanentemente o modo de abordá-los nos estudos. Ao invés do tratamento convencional das imagens dos relevos como objetos separados, catalogados e classificados a partir de seu tema e iconografia relativos a cada reinado, a perspectiva da autora chamou a atenção para o local desses objetos num espaço que era visto e percorrido, sendo tal disposição espacial um objeto de programação intencional e também portadora de sentido, ao lado da própria iconografia. Winter atentou à lógica da narrativa, isto é, ao conteúdo narrado e à estrutura narrativa sequencial, pois estava interessada em sua coerência, assumindo uma equivalência entre a narrativa histórica escrita e a visual. Assim, a textualidade informa a leitura daquilo que é expresso visualmente (WINTER, 1981, p. 2).

Tal abordagem, como destacou Bachelot (1991), não deixou de portar uma perspectiva cujo risco poderia ser um anacronismo no tratamento dessas imagens, ao trazer uma compreensão não condizente com as intenções de uso dos relevos no contexto assírio. Conforme o autor, o aspecto comunicativo tende a ser o significado principal das abordagens das mídias visuais, baseadas na cultura de massa e da propaganda. Ou seja, a interpretação padrão (nos termos de Nadali, 2020, p. 217) dos relevos como forma de propaganda im-

\footnotetext{
Uma narrativa visual ou um "espaço narrativo" (WINTER, 1981, p. 2) contempla a formação de uma cena por uma ou mais placas esculpidas que progridem a partir da interação de elementos esculpidos e solicitam uma espécie de acompanhamento visual e sequencial (WINTER, 1981; NADALI, 2006). Tal espaço narrativo envolve uma tensão estrutural entre o que está representado (o evento), como está sendo representado (por exemplo, o lugar do rei e de outras pessoas nas cenas, como as de guerra; a disposição vitoriosa assíria e representação da subjugação dos outros) e as razões dessa representação (os motivos pelos quais os relevos encontram-se no palácio real) (WINTER, 1981, p. 3). Winter (1981, p. 2-3) destaca que a palavra "narração" porta uma ideia de leitura, na qual a textualidade está implicada. Na visão da autora, a noção de espaço narrativo e de narrativa visual favorecem, de um lado, a compreensão da especificidade expressiva dos relevos e, de outro, o cuidado para não se empregar um modo de leitura textual à narratividade desse tipo escultórico.
} 
plicava uma audiência externa ampliada, já que suas imagens, especialmente as cenas de violência, deveriam ser direcionadas para afetar um público amplo. Contrariamente, para Bachelot (1991, p. 117), se houver mesmo uma lógica comunicativa, será alguma de tipo diferenciado e particular, para um grupo pequeno de indivíduos.

Esse debate está embebido na preocupação, emergida após a Segunda Guerra Mundial, em entender o consumo da cultura material, no sentido de "recepção da mensagem e expressão de valores em sistemas de comunicação", como "ato social criador de sentido", bem como sua interpretação e apropriação (REDE, 2012, p. 139). Além disso, a essa preocupação foram agregadas abordagens da semiologia, psicologia e psicanálise e antropologia do consumo, perfazendo um período alargado de quase três décadas, entre 1970 e 1990 . Essa consideração do enquadramento de preocupações advindas do âmbito das ciências humanas e sociais em torno da cultura material (REDE, 2012), em primeiro lugar, situa as contribuições de Winter (1981) e Bachelot (1991). Em segundo lugar, é interessante que, do ponto de vista teórico-metodológico, o debate não envolve somente uma implicação ou não com aspectos do consumo, fruto de uma noção de cultura de massa, mas também de articulação entre indivíduo (que percebe e interage) e o social, e como aspectos sociais servem para formar características individuais, ou identidades.

Assim, atenta-se a outros fatores que poderiam contribuir à interpretação sobre a função dos relevos palacianos assírios, a saber: suas audiências, o lugar da guerra e da violência como motivos iconográficos e suas condições de visibilidade. São bem destacadas na literatura as possíveis audiências dos relevos (FALES, 2006; LIVERANI, 2016; 2017): uma audiência real, composta por aqueles que viviam e circulavam nos palácios, bem como por alguns poucos convidados que visitavam áreas específicas, como as salas do trono; uma audiência real, mas futura, como os reis sucessores que devem cuidar dos registros textuais e imagéticos, e, no geral, dos feitos das construções monumentais de seus antepassados; e, por fim, uma audiência virtual, composta pelos deuses, a quem as obras são dedicadas e quem, inclusive, se convida para uma visita ritual quando da inauguração dos palácios.

Nota-se a vinculação dos palácios à guerra, o que pode ser observado pelas intenções da missão imperial dos soberanos assírios e pela presença dos relevos com motivos bélicos. As condições geopolíticas e históricas da região na primeira metade do I milênio A.E.C. favoreceram uma atividade militar sem precedentes, o que contribui, ao lado dos registros deixados em texto e imagem, para considerar a guerra como um elemento fundamental para a compreensão do contexto assírio. No entanto, ao se ponderar o lugar da 
guerra nesse ambiente, há de se ter cautela em não abordá-la como o motor principal da atividade imperial, evitando o risco de assumir, conforme Rede (2018, p. 599), uma "dupla ficção", seja das fontes provenientes da realeza palaciana, seja da produção historiográfica. Sem aparatos bem implementados para a organização do poder (como uma rede eficiente de comunicação e uma sistemática administrativa), um império assírio não teria existido. Nuançar esse espírito guerreiro alivia a interpretação exclusiva dos relevos palacianos como uma representação propagandista. Essa nuance permite de fato que se observe outras facetas tanto do lugar da guerra e da violência nos relevos, como a posição desses relevos no espaço palaciano.

Apesar das considerações sobre o papel propagandístico dos relevos, baseadas sobretudo nos motivos iconográficos que excessivamente expressam os feitos e vitórias, fato que fundamentaria a razão de que teriam servido para impactar audiências externas, há de se realçar suas nuances e notar a preeminência de uma audiência interna no contato cotidiano com as cenas dos relevos (BACHELOT, 1991; POZZER, 2013; REDE, 2018). Além disso, o acesso aos relevos é dependente do local do palácio, bem como das suas condições de visibilidade (BAGG, 2016), que implicam iluminação do ambiente, tamanho das figuras esculpidas, distância do observador com relação às placas com relevos e circulação pelas salas. Portanto, as imagens não estavam disponíveis para todos, nem eram visíveis por todos em todos os momentos. Isso não impede que os assírios quisessem que a imagem fosse vista desse modo, nem que eles quisessem que houvesse um impacto da imagem sobre seus observadores, nem que esses relevos com cenas de guerra fossem vistos ainda de outro modo pelos próprios assírios, produtores dos relevos. $\mathrm{O}$ modo como queriam que essas imagens fossem vistas e o modo como as enxergavam não necessariamente eram consonantes. Então, os relevos serviam não como propaganda, mas como materialização e comunhão, para os sujeitos no presente da época (os membros da corte e da família real) e para os futuros reinados, de um mesmo projeto de poder.

\section{Revisitando a sala 36 do palácio sudoeste de Nínive}

Os relevos da sala 36 remetem à terceira campanha no quarto ano de reinado de Senaqueribe, em 701 A.E.C., no Levante. Da entrada da sala 36 e voltados ao interior, a partir da sequência das placas, que nos conduzem a uma orientação mormente da esquerda à direita, teríamos três faces parietais ${ }^{2}$ : 1) a parede à esquerda (a sudeste, na orientação do palácio), com as placas

\footnotetext{
Veja a Figura 5 para um esquema representativo da sala 36.
} 
numeradas de 1 a 4, que nos são desconhecidas; 2) a parede de frente à entrada (a sudoeste), com as placas de 5 a 11; por fim, 3) a parede à direita (a noroeste), com as placas de 12 a 16. Nosso roteiro de observação privilegia a narrativa e os detalhes-chave que servem à nossa argumentação, a saber, a figura do rei e a presença da guerra e da violência.

Nas placas 5 e $6,{ }^{3}$ vemos filas de soldados armados num ambiente preenchido por alguns arbustos e parreiras e por pequenas ondulações, o que indica um terreno elevado. É a marcha para o assédio a uma cidade fortificada, utilizando rampas de assédio. Nas placas 7 e 8 (Figuras 1 e 2), temos o cerco à cidade em si.

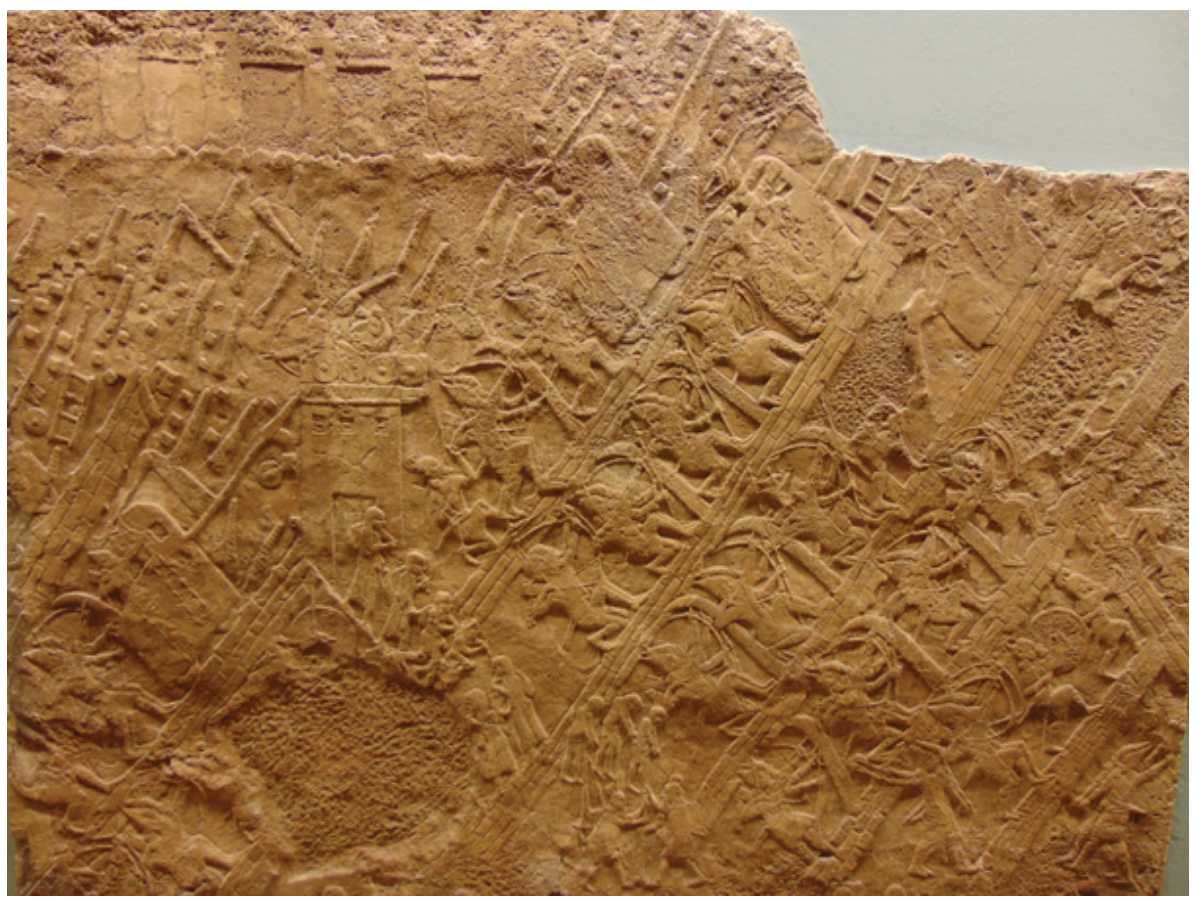

Figura 1: Relevos da sala 36 do Palácio Sudoeste de Nínive (placa 7)

Fonte: (C) The Trustees of the British Museum (BM 124906).

Produzida e adaptada pelo autor.

De acordo com nosso escopo de observação e para limitar o número de imagens no manuscrito, optamos por apresentar as placas que concentram elementos de interesse, como os momentos de assédio e procissão de pessoas e do butim. Para as imagens das placas remanescentes, veja, por exemplo, Pozzer (2013, esp. p. 25). Convidamos o(a) leitor(a) a ter contato com o acervo virtual do Museu Britânico de Londres, onde essas placas com relevos esculpidos estão em exposição permanente. Para a placa 6, veja https://www.britishmuseum.org/collection/object/W_1856-0909-14, acesso em 30 set. 2020. Por fim, veja também a nota de rodapé n. 5. 
Continuando da placa 6, à esquerda da placa 7 (Figura 1), há vários objetos soltos que parecem cair. Quase centralizada, há uma torre, com um grupo de soldados, numa situação defensiva. Mais acima na placa, há uma muralha. Vemos várias rampas com soldados e aríetes. Abaixo da torre, um grupo parece se deslocar, carregando uma espécie de bagagem sobre os ombros. Mais abaixo ainda, alguns soldados levantam corpos em pedaços de paus.

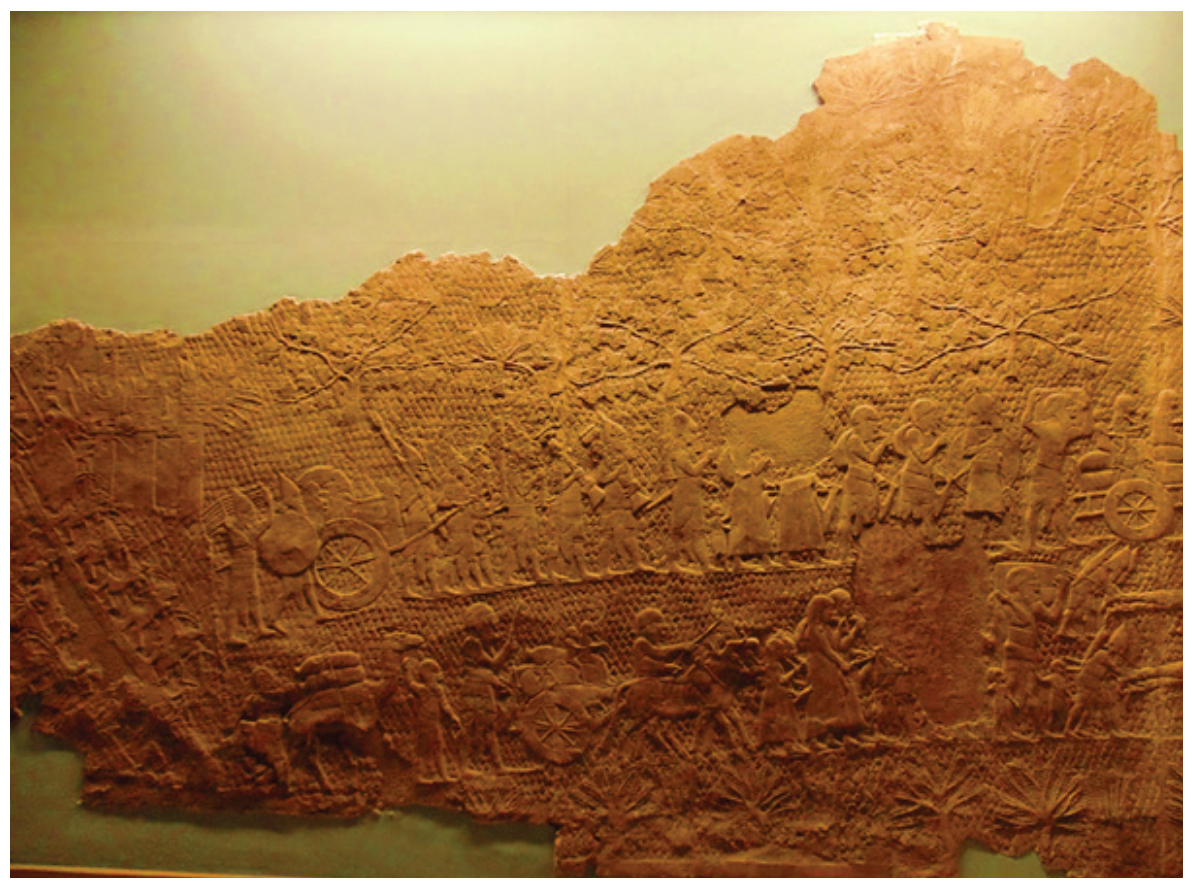

Figura 2: Relevos da sala 36 do Palácio Sudoeste de Nínive (placas 8 e 9) Fonte: (C) The Trustees of the British Museum (BM 124907-08).

Produzida e adaptada pelo autor.

Na Figura 2, apresentamos as placas 8 e 9 em conjunto. É interessante na placa 8 que a sua forma é espelhada em relação ao que vimos na placa 7 (Figura 1): na borda esquerda da placa 8 (Figura 2), temos o início de duas rampas que se inclinam, da direita à esquerda, à muralha. Vemos os arqueiros, lanceiros e um aríete. $\mathrm{Na}$ muralha, há algumas pessoas em posição de rendição.

Após uma sutil interrupção no terreno, na sequência há a retomada dos elementos paisagísticos naturais na parte mais alta das placas, com arbustos e videiras. Filas de pessoas são posicionadas em duas faixas. Vistas juntas, nas placas 8 e 9 (Figura 2) temos uma perspectiva mais alongada das duas filas de soldados e pessoas que se misturam em ambas as faixas. Há soldados assírios carregando objetos e especialmente um carro que, pelo tamanho e 
estilo, devia ser do soberano local. Ou seja, o butim está sendo levado. Na faixa mais abaixo, pessoas portam coisas num camelo e num carro puxado por um bovino, com crianças em cima desse.

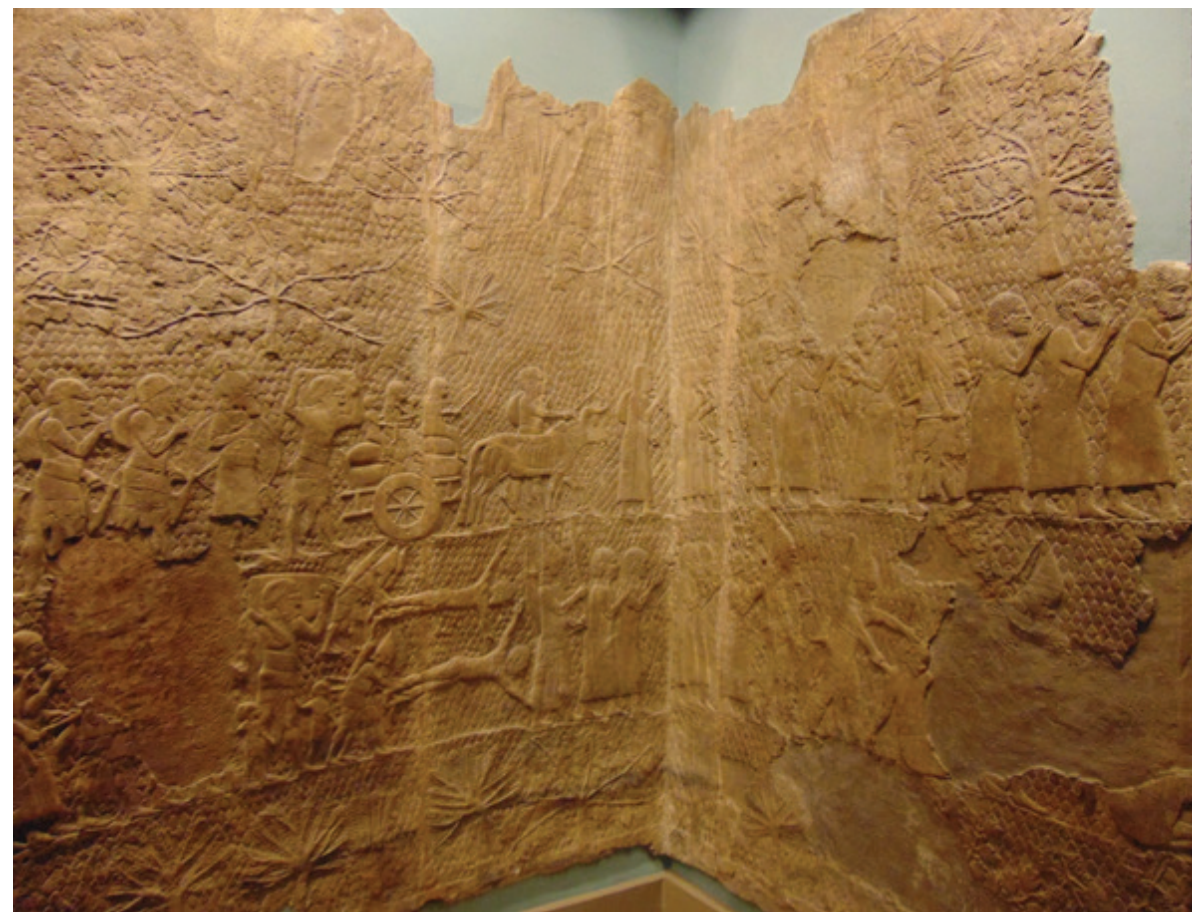

Figura 3: Relevos da sala 36 do Palácio Sudoeste de Nínive (placas 9 a 11)

Fonte: (C) The Trustees of the British Museum (BM 124908-10).

Produzida e adaptada pelo autor.

Nas placas de 9 a 11 (Figura 3), vemos a continuidade da procissão com a adequação das placas ao canto da sala do palácio. Na faixa acima, vemos criança e bebê; abaixo, vemos duas punições: dois sujeitos sendo jogados e outros dois sendo degolados, sendo o segundo inferido por uma reconstrução hipotética a partir da parte fragmentada da placa. Há também sujeitos com as mãos erguidas, o que pode indicar gesto de humildade e adoração.

Nota-se que, a partir da placa anterior (placa 8, Figura 2), cria-se uma terceira faixa na parte inferior, com aumento progressivo de sua largura, o que também ajuda a configurar a paisagem, bem como dá a impressão de que a cena se desenrola em elevação pelo cenário. 


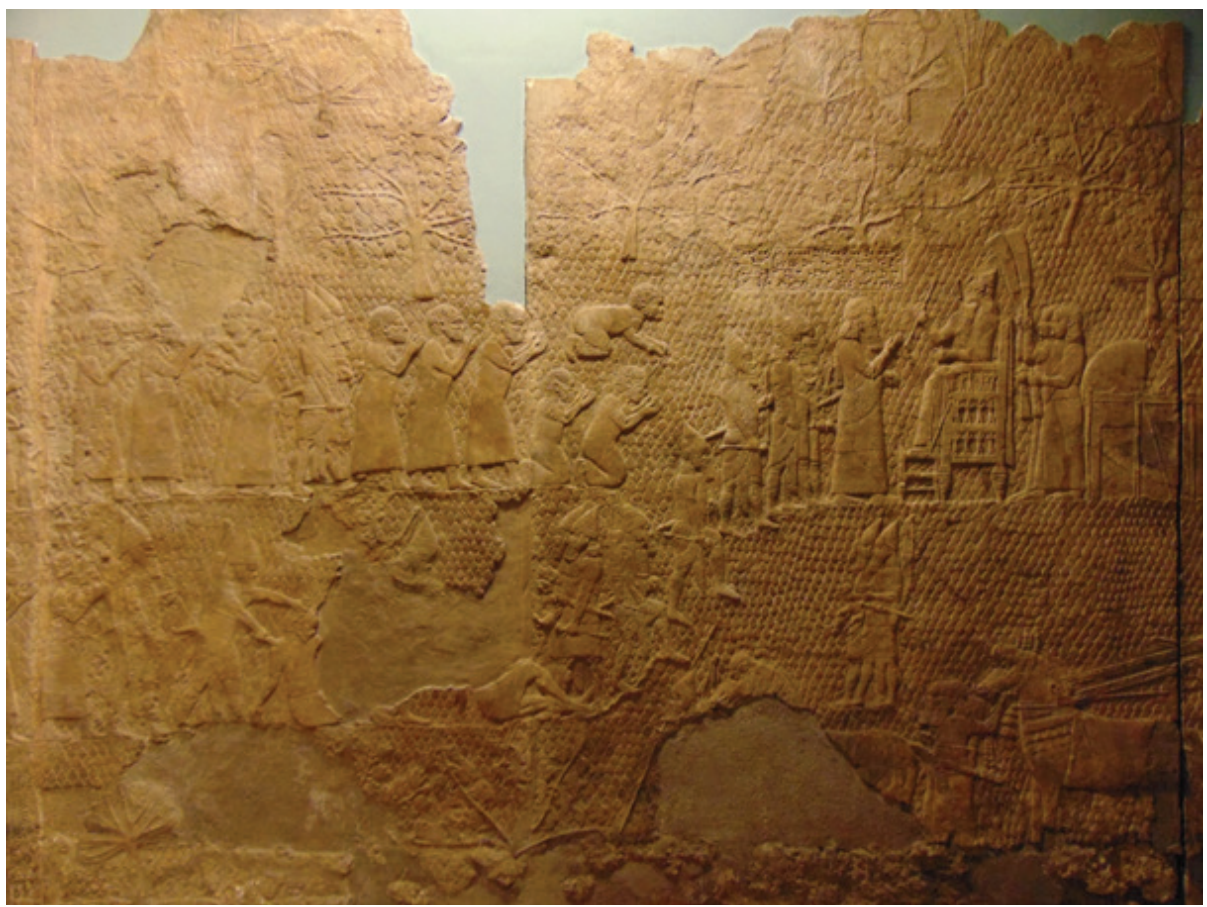

Figura 4: Relevos da sala 36 do Palácio Sudoeste de Nínive (placas 11 e 12)

Fonte: (C) The Trustees of the British Museum (BM 124910-11)

Produzida e adaptada pelo autor.

Encontramos duas faixas nas placas 11 e 12 (Figura 4), seguindo da esquerda para a direita. No início da faixa superior, há dois escribas em posição de anotação; na sequência, precedida por soldados, segue uma fila de pessoas com "braços levantados", com algumas delas se ajoelhando e uma em prostração. Mais adiante, soldados precedem uma pessoa, que está com uma mão levantada diante do rei em seu trono, e este está sendo abanado por trás pelos seus funcionários. A fila de soldados segue em direção ao rei, "subindo" uma elevação. Nota-se a presença de um texto enquadrado em meio à imagem: "Senaqueribe, rei do mundo, rei da Assíria, sentado em um cadeirão ${ }^{4}$ e o butim de Lachish, passando em revista diante dele". Atrás do rei e dos abanadores, há soldados voltados à esquerda e cavalos, o que inicia a caracterização do acampamento do rei.

\footnotetext{
4 Nessa inscrição, a palavra utilizada é nēmedu/nēmetu, com as acepções de cadeira, cadeira com encosto, descanso, e contrasta com o uso da palavra kussu para trono. Optamos por cadeirão para tentar diferenciar do objeto cadeira/assento e do assento/trono do palácio, assim como para destacar que é um objeto de luxo, especialmente observando suas figuras entalhadas.
} 
Por fim, nas últimas placas (13 a 16), ${ }^{5}$ temos a tenda do rei, seu carro real, com um protetor, mais soldados e cavalos, até chegarmos a uma espécie de fortificação, com outras tendas, animais e pessoas, caracterizando, então, o acampamento militar assírio.

\section{O lugar da guerra e da violência nos relevos da sala 36}

Após essa passagem em revista, reiteramos o percurso de acompanhamento pelas placas e a disposição arquitetural dos relevos, que expressam uma cena em etapas: marcha ao assédio, o ataque à cidade (Figuras $1 \mathrm{e}$ 2) e a procissão e contagem dos resultados diante do rei (Figuras 2 a 4). A figura do soberano na imagem se posiciona de modo a comandar, observar e receber os resultados da campanha. No percurso da cena, temos do assédio à submissão, ou seja, há um processo de controle e ordenação, típico elemento da figura do rei e da imagem da realeza. Além disso, há a elevação de Senaqueribe na cena, marcada por sua posição sentada no trono e pela linha percorrida pelas outras figuras humanas diante dele (Figura 4). Por um lado, realça-se sua dupla presença, no plano da imagem e da realidade, pois a cena evoca uma situação de acampamento militar na qual o rei poderia estar presente para observar o assédio à distância. Por outro lado, a figura do rei não é central na disposição arquitetural da sala, pois não se encontra nem numa posição medial no conjunto das placas, nem está numa posição tida como privilegiada, que seria diante da entrada da sala 36 (NADALI, 2006).

Novamente sobre a duplicidade da figura do rei, além de presente na cenografia e de participar da campanha, ele duplamente observa o evento: na cena em si (Figura 4) e na diagonal do espaço da sala (Figura 5). Sua posição, na placa 12 na parede noroeste, é de olhar à esquerda, em direção à parede sudoeste, nas placas 7 e 8 (Figuras 1 e 2), onde se dá o assédio à cidade nos relevos - e é a cena que está diante da entrada da sala.

\footnotetext{
Com relação às placas 13 a 16, que trazem elementos secundários de acordo com nosso escopo de observação, optamos por não as apresentar no corpo do texto para limitar o número de imagens no manuscrito. Estimulamos o(a) leitor(a) a consultar essas imagens no acervo digital do Museu Britânico. Uma fotografia conjunta das placas 11 a 13 está disponível em: https://www.britishmuseum.org/ collection/object/W_1856-0909-14_6, acesso em: 30 set. 2020. Já uma fotografia conjunta das placas 14 a 16 está disponível em: https://www.britishmuseum.org/collection/object/W_1856-0909-14_9, acesso em: 30 set. 2020.
} 


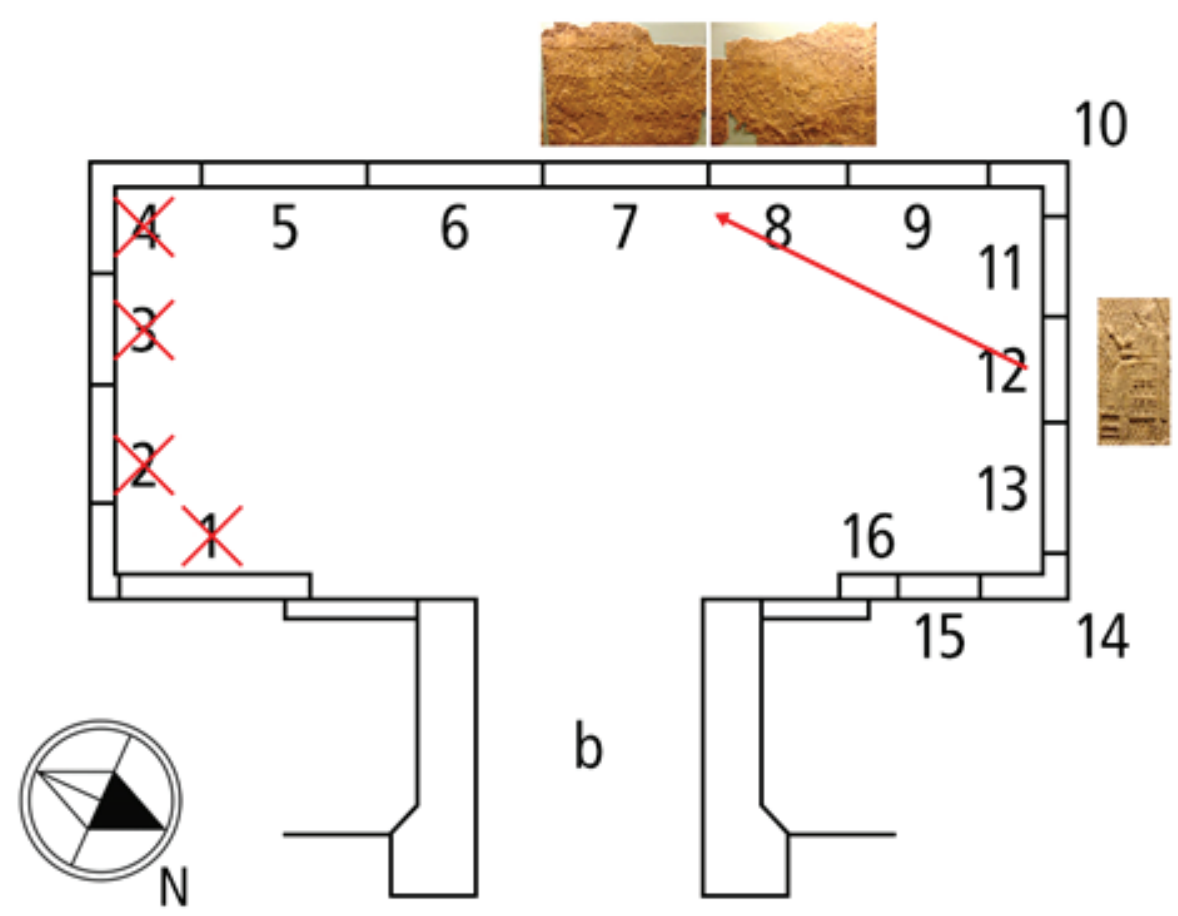

Figura 5: Esquema representativo da sala 36 do palácio sudoeste de Nínive, com disposição e numeração das placas parietais com relevos esculpidos.

Fonte: Baseado em Barnett, Bleibtreu e Turner (1998, prancha 322).

Elaborado e adaptado pelo autor.

Nesse processo, há a presença da violência, seja do assédio em si (Figuras 1 e 2), seja dos corpos empalados (Figura 1) e jogados (Figura 3), seja do sujeito degolado (Figuras 3 e 4) e da sujeição de todos os outros (Figuras 2 a 4). A guerra é um motivo proeminente dentre os relevos palacianos, bem como nas inscrições reais. Pelo menos metade das salas conhecidas dos palácios assírios contém cenas de guerra e violência, incluindo todos os elementos: assédio às cidades e procissão de butins e deportados. Então, cenas de guerra e violência não se concentram em espaços ditos mais públicos do palácio, nem somente em espaços clara e estritamente cerimoniais (por exemplo, as salas do trono), mas são cenas mais dispersas pelas paredes de diferentes salas dos palácios.

Num primeiro momento, pode-se pensar que haja contraste entre cena de violência e sem violência no conjunto das placas com relevos da sala 36 . A princípio, há a parte do assédio e os pontos com punições (respectivamente Figuras 1-2 e 1, 3-4). Contudo, a violência está em toda parte, pois, 
mesmo com a presença do rei, o conjunto é uma situação bélica. Mesmo com o contraste entre assédio e ordenamento como resultado da ação assíria, a violência está presente em toda a cena, inclusive na organização do acampamento assírio, que é um acampamento militar. Além disso, o rei está diante tanto do assédio, como da violência. Se é ele quem comanda e colhe os resultados da campanha, a violência faz parte de sua atuação.

Até aqui, as considerações sobre a guerra e violência nesse conjunto de relevos estão num patamar mais geral e, apesar de esses relevos só existirem porque se fez a guerra, há uma gradação entre o evento da batalha e o que vem depois, obedecendo a um certo ordenamento - sem deixar de ser também algo violento, como já dito. Conforme Bang (2021, p. 14), isso é um corolário da destruição e colonização imperial, a saber: a existência e a presença de memórias da destruição, com as quais todos têm que viver, inclusive quem faz a guerra e é agente da dominação. Assim, essas imagens respondem a, são informadas por e são frutos dos desenvolvimentos políticos. Elas tornam razoável a guerra para a comunidade palaciana (BACHELOT, 1991; COLLINS, 2014). Contudo, mais especificamente, as cenas de violência e brutalidade, exceto na parte de assédio propriamente dito (placas 7 e 8 nas Figuras 1 e 2), se dão de modo pontual em meio às filas de procissão, com outras pessoas. Então, mais do que a brutalidade em si, a pontualidade dessas figuras nos faz pensar em "punições exemplares", que não teriam sido arbitrárias, conforme entendemos com Bagg (2016), mas, sim, são situadas, no plano da imagem, em meio a outras pessoas. Assim, podem haver três elementos em jogo: o primeiro é uma conotação realista, de que algo aconteceu em meio a outros, sendo visto por testemunhas; o segundo elemento é uma espécie de conotação pedagógica, que deixa claro aos outros, de crianças a adultos, a importância da "obediência" aos assírios, algo que as inscrições reais também fazem questão de chamar a atenção, ao englobar a totalidade dos indivíduos nos efeitos da atuação assíria; e, sobretudo, o terceiro elemento é a punição enquadrada numa espécie de gênero, de um conteúdo que é difundido dentro do espaço palaciano.

Contudo, essas imagens da violência são para quem? Se a violência em meio à atuação bélica faz parte da atuação do rei, a imagem da violência tem um sentido ou razão de ser violenta. Ou seja, parafraseando Rede (2018), é uma imagem da violência e uma violência da imagem. No entanto, novamente, é uma imagem para quem? Observar o local de disposição dessa imagem pode favorecer um entendimento sobre a quem ela se destina.

É válido destacar que essa sala 36 faz parte de um setor específico do palácio de Senaqueribe, estando localizada numa terceira fila de salas menores: 
na Figura 6, que é um plano baixo do palácio sudoeste de Nínive, a sala 36 está aproximadamente no centro do quadrante inferior direito da figura, estando preenchida em cinza. Segundo Kertai (2015), esse setor obedece a uma lógica de maior restrição de acesso e circulação - bem como de seu afastamento de um setor mais acessível, como a área da sala do trono (na parte superior da Figura 6, em laranja, Throneroom) -, ao mesmo tempo que, ao ser uma parte do palácio que conta com um pátio, ganha amplitude monumental. Além desse aspecto, um pátio favorece a iluminação natural nas salas em seu entorno. Então, para o caso da sala 36, ser um recinto numa terceira fila de distância em relação ao pátio dificultaria uma iluminação adequada. Há entre 15 e 20 metros do portal do pátio (o Courtyard 10 na Figura 6), que seria uma área descoberta, até a parede sudoeste da sala 36, diante de sua entrada. Ou seja, ou a sala era mais escura por causa de seu distanciamento do pátio, ou haveria iluminação artificial no recinto. ${ }^{6}$

Por estar mais entranhada no interior do palácio, a audiência devia ser mais restrita, o que retoma a questão de a quem servem essas imagens. Os aspectos espaciais e arquiteturais nos fazem pensar novamente na ênfase numa comunidade interna, para fins de um autoconsumo - e, em complemento, de um autoconvencimento (LIVERANI, 2016; 2017). Entender as razões da ação violenta, que faz parte da ação imperial e para convencer de sua razão de ser, ao mesmo tempo que estimula a guerra como parte do projeto imperial, faz todos aqueles da comunidade interna do palácio se sentirem coligados ao mesmo projeto - e, em geral, entenderem as imagens, ou ao menos seu propósito geral.

\section{Espaço palaciano e relevos parietais como componentes de uma cerimônia da memória}

O caso dos relevos de Lachish são intrigantes não só pela sua disponibilidade - é um dos poucos conjuntos de placas quase completo e de um único evento -, mas também pela sua localização no espaço palaciano. Como vimos, o recinto fica no fim de uma espécie de corredor formado pelas entradas de duas grandes salas alongadas e retangulares (salas 29 e 34, na Figura 6). É possível que esse setor do palácio, especialmente com a presença dessas salas retangulares maiores e com três salas menores (salas 35 a 37, na Figura 6), concentrasse outros conjuntos de relevos com cenas de guerra. Conforme

\footnotetext{
${ }^{6}$ Veja também Battini (2019). Para uma reconstrução hipotética em 3D da sala, veja o projeto de Learning Sites. Disponível em http://www.learningsites.com/Nineveh/SWP Nineveh home.php, acessado em: 30 set. 2020 .
} 


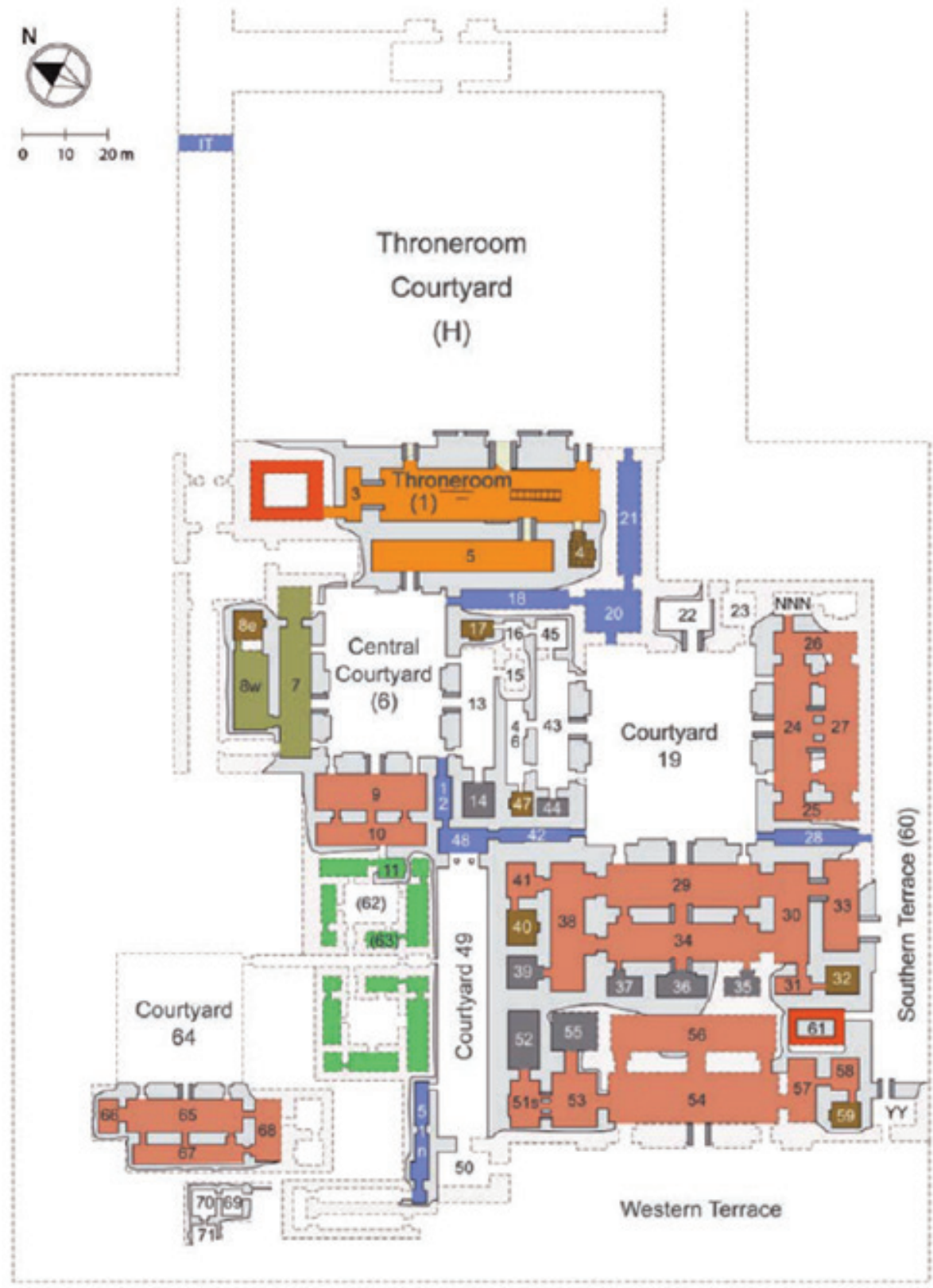

Figura 6: Plano baixo do Palácio Sudoeste de Nínive, com enquadramento em vermelho da sala 36 aproximadamente no centro do quadrante inferior direito da figura.

Fonte: Fonte: KERTAI, 2015, fig. 17. (C) David Kertai. Adaptado pelo autor. 
Barnett, Bleibtreu e Turner (1998, p. 91-105), algumas dessas salas ainda tinham placas não esculpidas, como é o caso da sala $29 .^{7}$ O que se sabe da sala 34 é por meio de desenhos de A. H. Layard (1817-1894), primeiro escavador das ruínas do palácio em meados do séc. XIX de nossa Era, que mostram cenas de cativos, parecidos com as da sala 36. A sala 35 não é conhecida. A sala 37 foi encontrada destruída. Então, os autores propõem que as salas 34 a 37 fossem dedicadas à terceira campanha de Senaqueribe no Levante.

Até aqui, considerando que $1^{\circ}$ ) o lugar das salas num dado setor pode nos ajudar a pensar sobre a movimentação pelo palácio, especialmente a circulação e restrição do recinto; e $2^{\circ}$ ) salas com relevos, que se avizinham de alguma forma num dado setor, podem servir para uma exposição mais alongada de um tema, ou até um setor que se vale de um tipo específico de motivo: nesse sentido, talvez esse setor no qual a sala 36 se encontra formasse um ambiente cerimonial específico, com vários recintos com cenas de batalhas e provavelmente com acessibilidade reduzida. Assim, reforça-se a ideia de que tenha sido um espaço para poucas pessoas e de dedicação específica, como um compartimento temático.

Retomando a interface dos relevos da sala $36 \mathrm{com}$ fontes textuais, ambos remetem ao mesmo evento: a terceira campanha, no quarto ano de reinado de Senaqueribe, em 701 A.E.C., no Levante, especialmente envolvendo o cerco à Jerusalém - que conta inclusive com paralelos bíblicos -, e a destruição da cidade de Lachish. No entanto, uma e outra fonte registram o evento de modo diferente. De um lado, nas inscrições, temos as razões das atitudes dos outros que levam à atuação assíria; ${ }^{8}$ por outro, a atuação assíria é enfatizada nos relevos - e as razões ficam implícitas, por exemplo, nos atos de punições (BAGG, 2016).

Mesmo com essa diferença de ênfase, e da mesma forma que as inscrições reais são produzidas solicitando sua proteção pelas gerações futuras dos reis 9 - e eram tanto constituidoras da "estrutura física dos palácios" (RUSSELL, 1999, p. 6), pela sua presença nas paredes, portais e soleiras, como, em muitos casos, eram inscritas em objetos diversos e escondidas nas bases de paredes ${ }^{10}$ - os relevos foram produzidos para registrar as ações da

Isso se aplica também à sala 30 (BARNETT; BLEIBTREU; TURNER, 1998, p. 91).

8 Para uma edição de uma inscrição que traz o relato da terceira campanha de Senaqueribe, veja o texto 4 em Grayson e Novotny (2012, p. 55-69, RINAP 3/1 4), especialmente as linhas 32 a 60, também disponível em: http://oracc.iaas.upenn.edu/rinap/rinap3/Q003478/html, acesso em: 28 set. 2020.

9 Conforme o exemplo citado na nota de rodapé n. 8, as linhas 93 e 94 tratam especificamente dessa dedicação da inscrição.

10 Sobre a colocação de diversos tipos de suportes contendo inscrições reais nas paredes não só dos palácios, mas de outros locais de Nínive, veja Grayson e Novotny (2012). 
realeza e foram preservados para o futuro. É válido lembrar, com a ajuda de Nadali (2020), que os espaços palacianos eram habitados e frequentados por sucessivos reis e há ocorrências de transferências de placas com relevos esculpidos entre palácios em diferentes reinados. Sendo assim, a colocação dos relevos num setor mais entranhado no complexo palaciano nos parece uma atitude similar à de preservação das inscrições em locais escondidos, o que envolve a celebração dos feitos no presente e sua recuperação no futuro.

A isso se alinha o argumento de Jones (2007, p. 44-45) sobre comemorações por meio da cultura material, que tendem a ser formalizadas, não arbitrárias e envolvem modos e meios de rememoração e recorrência, que por sua vez permitem a continuidade de uma tradição, mesmo com mudanças sutis ao longo do tempo. ${ }^{11} \mathrm{O}$ objeto comemorado e as coisas que o representam habilitam o que deve ser lembrado na presença e com a atuação dos sujeitos envolvidos. Ou seja, a comemoração, em paralelo ao que chamamos aqui de cerimônia, dá o enquadramento para a lembrança (JONES, 2007, p. 46). Por isso, coligando o propósito memorial dos relevos à dedicação cerimonial dos espaços palacianos, aventamos a noção de cerimônia da memória como uma das funções desses recintos.

Os elementos adicionais sobre a sala 36 corroboram com outras análises presentes na literatura, o que contribui para a nossa proposição da noção de cerimônia da memória.

É frequente a consideração das funções cerimoniais de certos espaços palacianos (BRANDES, 1970; RUSSELL, 1998; RICHARDSON, 1999-2001; BARJAMOVIC, 2011; KERTAI, 2015; NADALI, 2015), incluindo os locais de banquetes e a comensalidade em si (RUSSELL, 1998; WINTER, 2013). Encontramos argumentos na literatura sobre a possibilidade de uso do espaço palaciano como espaço de culto (RICHARDSON, 1999-2001; BROWN, 2010). Richardson (1999-2001) argumentou que todo o programa dos relevos no palácio de Assurnasirpal II, no séc. IX A.E.C., representava uma intenção de garantir um lugar para a memória dos reis ancestrais da Assíria - por isso que a imagem do rei era predominante em mais de um setor daquele palácio. Além disso, o autor propôs a existência de uma espécie de culto aos ancestrais, que era materializado pelos numerosos relevos de árvores estilizadas nos cantos das salas, cada um, segundo o autor, representando um rei antepassado. Já Brown (2010) concorda sobre algum tipo de ritual de culto aos ancestrais materializado no mesmo palácio, mas destaca que tal culto estava baseado em ritos funerários das práticas mortuárias assírias; tais ritos eram conduzidos,

11 Sobre esses aspectos repetitivos para a preservação memorial, veja também os argumentos de Gansell (2016, esp. p. 86-92), Di Paolo (2016, esp. p. 152) e Nadali (2016; 2020). 
conforme o autor, em uma área específica do palácio, "dedicada à realização de rituais relacionados à comemoração e cuidado dos ancestrais" (p. 20).

Nadali (2020) também enfatiza o aspecto memorial dos palácios assírios, com seus textos e imagens, por meio da noção de memória como um tipo de tecnologia e dispositivo de conhecimento. Nesse sentido, os textos e imagens servem a uma preservação da memória dos antepassados - o que fazia parte do presente vivido pelos reis (p. 224) -, bem como da própria realeza, também incorporada na pessoa do rei. Ou seja, não somente o palácio, mas o próprio rei, como expressão da realeza, incorpora memórias. O rei, o palácio, seus textos e imagens permitem o reconhecimento desses lugares de memórias, com todo seu "aparato herdado do passado" (p. 225). Conforme o autor, o passado registrado nos textos e imagens palacianos está sempre diante dos olhos daqueles que vivem no palácio, criando espaços memoriais ou "espaços mnemônicos" (p. 227). Então, a memória faz parte da visualidade da comunidade palaciana (p. 226).

$\mathrm{Na}$ mesma linha, Gansell (2016) defende a existência de uma "memória ideológica da elite" (p. 86) que sustenta a produção de motivos similares nos relevos palacianos ao longo do período neoassírio e que é fundamentada e reforçada entre gerações por esta memória (p. 87). Conforme a autora, como também Di Paolo (2016, p. 156) e Nadali (2016), a unidade dessa memória contava com a figura do rei, como "veículo da memória e da realeza” (GANSELL, 2016, p. 86). A figura do rei é unificadora da ação, tanto daqueles que participam da missão imperial, como da comunidade vindoura dos participantes (DI PAOLO, 2016, p. 156). Então,

[...] inserindo a história do rei em uma narrativa perene que residia nas paredes palacianas, imagens e inscrições autorreflexivas também poderiam ter lembrado o rei e outros observadores do que ele fez, do que seus ancestrais fizeram, do que é sempre feito e, portanto, do que ele e seus sucessores farão. (GANSELL, 2016, p. 91-92).

Já Ataç (2016, p. 70-71) argumenta que o conteúdo dessa memória dos relevos é referente aos eventos do período médioassírio, o que o constituiria uma espécie de passado mítico e memorial e que perfaz a "consciência histórica” do período neoassírio. Tal carga memorial, na visão do autor, valoriza a produção desse tipo de representação. Repetir a representação da guerra, com conotação sagrada e cerimonial, num espaço específico - as paredes do palácio - pode ser tão importante quanto guerrear.

Tendo em vista os elementos levantados até aqui, a função memorial dos relevos se fundamenta tanto em seu conteúdo (a composição de relato visual de uma campanha militar historicamente realizada), como em seu local 
de disposição. Novamente, sua colocação num espaço recuado do palácio é similar ao posicionamento de algumas das inscrições reais assírias em locais específicos e escondidos na parede. Ou seja, não são registros para serem vistos, mas para serem produzidos, guardados e preservados pelos reis assírios nos palácios. Conforme Nadali (2016, p. 43), "não era importante que esses sinais fossem visíveis: era muito mais importante e útil saber que eles estavam lá, atuando por si próprios para a proteção da construção e garantindo a transmissão da memória para o futuro".

Esse princípio de colocação das inscrições e dos relevos em lugares reclusos se assemelha tipicamente a outras práticas deposicionais com fins memoriais. Conforme Mills (2008, p. 82), a deposição de objetos fora do alcance, especialmente visual, é uma das formas de memória; esses objetos, mesmo inalcançáveis, podem ter sido ritualmente elaborados, bem como podem ser lembrados por longos períodos. Knappett (2011, p. 200-201) menciona a estruturação intencional de objetos para que fiquem ausentes, não sendo, então, meramente um descarte. Assim, em paralelo a Mills e Walker (2008, p. 7), elementos propriamente celebratórios, como é o caso das narrativas, textuais e visuais, dos feitos do soberano assírio, ao serem incorporados materialmente aos palácios, passam a ser cotidianos. Sendo assim, o cotidiano é marcado por elementos de comemoração e, vice-versa, a comemoração se torna cotidiana. A repetição do conteúdo celebrado e da prática de reclusão habilita a memória (MILLS; WALKER, 2008, p. 9; MILLS, 2008; KNAPPETT, 2011).

Portanto, há uma similaridade entre a produção dos relevos e das inscrições, como registros a ser preservados e materializados em espaços específicos, sobretudo as paredes dos palácios. Esses textos e imagens são destinados a uma comunidade interna não só pela restrição de acesso ou por um eventual código ou conteúdo que só seria entendido por ela, mas justamente por serem guardados, menos expostos ou algo íntimo para aquele grupo - daí um tom cerimonial para a comunidade palaciana. Com relação a esses compartimentos espaciais e temáticos, emprestamos a noção de "atividades incorporadoras" (MILLS, 2008, p. 99), para nos referirmos à colocação intencional desses objetos no corpo dos palácios assírios, tornando os espaços e esses objetos "consubstanciais" e de dedicação ritual. O aspecto cerimonial - e memorial - vivido pela corte faz parte da missão imperial assíria. Portanto, a memória teria uma tripla função por meio dos relevos: lidar com o passado, relembrá-lo no presente em conjunto com a missão imperial (BACHELOT, 1991; NADALI, 2019b) e preservar passado e presente para os futuros soberanos. 
Como vimos, por meio dessa relação entre passado e futuro, há a apropriação dos relevos por parte dos sucessivos soberanos, o que nos faz destacar a geração como elemento importante da realeza assíria, tanto em termos ideológicos, como em termos de uma prática da memória. A afirmação de Knappett é representativa nesse sentido: "um ritual de transferência de um objeto de uma geração para a próxima teria servido para consolidar e sustentar memórias particulares conectadas com o objeto" (2011, p. 193). Tal processo geracional é similar tanto à destinação declarada nas inscrições reais aos reis futuros - para preservar essas mesmas inscrições -, como à destinação dos relevos, que permaneceriam nos palácios, sendo esses espaços, como lembrou Nadali (2020), também objetos de (re)uso e (re)apropriação por sucessivas gerações de reis.

Uma cerimônia da memória depende também não só da forma da sala, sua localização no palácio e da iconografia presente nos relevos parietais, mas também da performance, vista especialmente a partir do fluxo de movimentação. As divisões espaciais no palácio, obedecendo a setorizações (KERTAI, 2015), podem exercer e enfatizar a ordem e a hierarquia da corte palaciana. Ao lado de todos os elementos presentes no palácio que podem ser considerados símbolos do poder (BARJAMOVIC, 2021, p. 97), ordem e hierarquia no uso e movimentação pelo palácio se articulam a protocolos de conduta, ao mesmo tempo que promovem uma consciência social ou coletiva (BARJAMOVIC, 2011, p. 44). Mesmo que um comportamento ritualizado costume ser de difícil inferência a partir das fontes disponíveis, o deslocamento corporal pode ser um aspecto estimulado tanto pelo formato da sala, como pelos elementos iconográficos (BRANDES, 1970; RUSSELL, 1998; BROWN, 2010; PORTUESE, 2019). Como nos lembra Laneri (2016), aspectos corporais fazem parte e contribuem para a constituição da memória por meio de rituais. Uma "performance comemorativa", que Laneri retoma de Jones (2007), "envolve participação corporal por meio de um engajamento com lugares e objetos, o qual repentinamente torna-se uma prática conectiva que reúne pessoas e coisas em atos de memória" (LANERI, 2016, p. 6162). Como vimos, os relevos da sala 36 do palácio sudoeste de Senaqueribe possuem uma narrativa sequencial, o que favorece o deslocamento ocular e corporal. Dependeríamos de um estudo a parte, mas, contrastando com a literatura já existente especialmente sobre as salas dos tronos (WINTER, 1981; NADALI, 2008; 2019a; PORTUESE, 2019), salas alongadas (BRANDES, 1970), corredores (NADALI, 2006, MCMAHON, 2013) e sobre a coligação entre áreas do palácio (RICHARDSON, 1999-2001; NADALI, 2006; BROWN, 2010), é possível pensar que o fluxo de circulação e a luminosidade da sala 
fossem reduzidos também de acordo com a forma e tipo de relevo. Figuras esculpidas em maior número e em tamanho menor num conjunto cenográfico sequencial poderiam exigir um deslocamento mais lento e mais aproximado em relação aos relevos. Ou seja, uma cerimônia da memória implica imagens e a espacialidade, em termos das possibilidades de deslocamento corporal e da percepção visual no recinto palaciano.

\section{Considerações finais}

Propusemos a noção de cerimônia da memória como uma função da sala 36 do palácio sudoeste de Nínive. Após uma passagem em revista pelo seu conjunto de relevos parietais, destacamos o lugar de seus elementos iconográficos, especialmente a narrativa, a figura do rei e a guerra e a violência. Esses elementos ensejaram nossa discussão sobre a audiência, a acessibilidade dessa sala e sua destinação à comunidade palaciana. Considerando a semelhança entre a forma de preservação desses relevos e das inscrições reais, ambos entranhados no espaço palaciano, acreditamos que a produção desses relevos e a sua existência nessa sala, num setor específico do palácio, proponham uma atitude em relação ao presente e em direção ao futuro. Cerimônia da memória parece ser uma expressão que conflui todos os aspectos desse fenômeno material, que é a existência desses relevos no espaço palaciano em interação com uma corte que os produz e convive com esses objetos. Consideramos, inclusive, que o propósito dos relevos e das salas contempla tanto a dimensão cerimonial, como a memorial: os relevos são objetos memoriais em espaços cerimoniais e as salas palacianas são espaços memoriais com objetos cerimoniais.

Seria preciso revisar outros espaços dos relevos para testar essa mesma possibilidade, a saber, dentre as outras funções e usos para as salas dos palácios, alguns recintos fossem dedicados à compartimentação de temas, nesse caso com um aspecto memorialístico e cerimonial. Talvez uma das razões de produção dos relevos tenha se tornado justamente essa preservação da memória após a necessidade de materialização no palácio deste tipo de relato, a partir do séc. IX A.E.C., com a fundação da nova capital Nimrud e o novo palácio, por Assurnasirpal II. Isso levaria a revermos e ampliarmos nossa concepção de palácio, realçando-o também como lugar de memória, bem com a noção de prática da memória que conta com um aspecto cerimonial. Não acreditamos que esta interpretação seja igualmente válida para todos os outros espaços palacianos, mas todos os espaços semelhantes à condição da sala 36 no conjunto arquitetural e com relevos parietais têm esse potencial 
cerimonial e possivelmente memorialístico. Imagens dos relevos, que incluem a violência e a guerra como parte integrante da ideologia assíria, servem para entender a formação de uma memória, que não era para ser largamente vista, mas só e sabidamente produzida e guardada para alguns sujeitos que faziam parte do palácio.

\section{Referências bibliográficas}

ATAÇ, Mehmet-Ali. The historical memory of the Late Bronze Age in the Neo-Assyrian palace reliefs. In: NADALI, Davide (org.). Envisioning the past through memories. (How Memory Shaped Ancient Near Eastern Societies). London: Bloomsbury, 2016, p. 69-83.

BACHELOT, Luc. La fonction politique des reliefs néo-assyriens. In: CHARPIN, Dominique; JOANNÈS, Francis (orgs.). Marchands, diplomats et empereurs. Études sur la civilization mésopotamienne offerts à Paul Garelli. Paris: Éditions Recherche sur le Civilisations, 1991, p. 109-128.

BAGG, Ariel M. Where is the public? A new look at the brutality scenes in Neo-Assyrian royal inscriptions and art. In: BATTINI, Laura (org.). Making pictures of war. (Realia et Imaginaria in the Iconology of the Ancient Near East). Oxford: Archeopress, 2016, p. 57-82.

BANG, Peter F. Empire-A World History. Anatomy and concept, theory and synthesis. In: BANG, Peter F.; BAYLY, Christopher A.; SCHEIDEL, Walter (orgs.). The Oxford World History of Empire. Vol. 2: The History of Empires. Oxford: Oxford University Press, 2021, p. 1-87.

BARJAMOVIC, Gojko. Pride, pomp and circumstance: palace, court and household in Assyria 879-612 BCE. In: DUINDAM, Jeroen; ARTAN, Tülay; KUNT, Metin (orgs.). Royal courts in dynastic States and Empires. A Global Perspective. Leiden: Brill, 2011, p. 27-61.

BARJAMOVIC, Gojko. The empires of Western Asia and the Assyrian World empire. In: BANG, Peter F.; BAYLY, Christopher A.; SCHEIDEL, Walter (orgs.). The Oxford World History of Empire. Vol. 2: The History of Empires. Oxford: Oxford University Press, 2021, p. $73-110$.

BARNETT, Richard David; BLEIBTREU, Erika; TURNER, Geoffrey. Sculptures from the Southwest Palace of Sennacherib at Nineveh. London: British Museum, 1998.

BATTINI, Laura. Light as experience: rethinking Neo-Assyrian reliefs in their architectural context. Ash Sharq, v. 2, p. 69-104, 2019.

BRANDES, Mark. La salle ditte G du palais d'Assurnasipal II à Kalakh, lieu de cérémonie rituelle. In: FINET, André (org.). Actes de la XVII Rencontre Assyriologique Internationale, 1969. Ham-sur-Heure: Comité Belge de Recherches en Mésopotamie, 1970, p. 147-154.

BROWN, Brian. Kingship and ancestral cult in the Northwest Palace at Nimrud. Journal of Ancient Near Eastern Religions, v. 10, n. 1, p. 1-53, 2010.

COLLINS, Paul. Gods, heroes, rituals, and violence: warfare in Neo-Assyrian art. In: BROWN, Brian A.; FELDMAN, Marian H. (orgs.). Critical approaches to ancient Near Eastern art. Boston; Berlin: Walter de Gruyter, 2014, p. 619-644. 
DI PAOLO, Silvana. War remembrance narrative: negotiation of memory and oblivion in Mesopotamian art. In: NADALI, Davide (org.). Envisioning the past through memories. How memory shaped ancient Near Eastern societies. London: Bloomsbury, 2016, p. 143-162.

FALES, Frederick Mario. Narrazione visuale e testuale: il caso delle campagne militari assire. In: Vv.Aa. (orgs.). L'arte nel vicino oriente antico: bellezza, rappresentazione, espressione. (Centro Studi del Vicino Oriente). Milano: Ares, 2006, p. 79-116.

GANSELL, Amy R. Prioritized presence: rulers' images in the Neo-Assyrian palace as devices of elite ideological memory. In: NADALI, Davide (org.). Envisioning the past through memories. (How Memory Shaped Ancient Near Eastern Societies). London: Bloomsbury, 2016, p. 85-100.

GRAYSON, Albert Kirk; NOVOTNY, Jamie. Introduction. In: GRAYSON, Albert Kirk; NOVOTNY, Jamie (orgs.). The royal inscriptions of Sennacherib, king of Assyria (704-681 BC), Part 1. (The Royal Inscriptions of the Neo-Assyrian Period, RINAP, v. 3, n. 1). Winona Lake: Eisenbrauns, 2012, p. 1-26.

GROß, Melanie; KERTAI, David. Becoming empire: Neo-Assyrian palaces and the creation of courtly culture. Journal of Ancient History, v. 7, n. 1, p. 1-31, 2019. Disponível em: https://www.degruyter.com/document/doi/10.1515/jah-2018-0026/html. Acesso em: 19 jan. 2021.

JONES, Andrew. From memory to commemoration. In: JONES, Andrew. Memory and Material Culture. Cambridge: Cambridge University Press, 2007, p. 27-46.

KERTAI, David. The architecture of late Assyrian royal palaces. Oxford: Oxford University Press, 2015.

KNAPPETT, Carl. Temporalities and biographical care. In KNAPPETT, Carl. An archaeology of interaction: network perspectives on material culture and society. Oxford: Oxford University Press Oxford, 2011, p. 191-213.

LANERI, Nicola. Embodying the memory of the royal ancestors in Western Syria during the Third and Second Millenia BC: the case of Ebla and Qatna. In: NADALI, Davide (org.). Envisioning the past through memories. (How Memory Shaped Ancient Near Eastern Societies). London: Bloomsbury, 2016, p. 53-67.

LIVERANI, Mario. Antigo Oriente: história, sociedade e economia. Trad. I. E. Rocha. São Paulo: Edusp, 2016.

LIVERANI, Mario. Assiria. La preistoria dell'imperialismo. Bari: Laterza, 2017.

MCMAHON, Augusta. Space, sound, and light: toward a sensory experience of ancient monumental architecture. American Journal of Archaeology, v. 117, n. 2, p. 163-179, 2013.

MILLS, Barbara J. Remembering while forgetting. Depositional practices and social memory at Chaco. In: MILLS, Barbara J.; WALKER, William H. (orgs.). Memory work: archaeologies of material practices. Santa Fe: School for Advanced Research Press, 2008, p. 81-108.

MILLS, Barbara J.; WALKER, Willian H. Introduction. Memory, materiality and depositional practice. In: MILLS, Barbara J.; WALKER, Willian H. (orgs.). Memory work: archaeologies of material practices. Illustrated edition. Santa Fe: School for Advanced Research Press, 2008. p. 3-23. 
NADALI, Davide. Percezione dello spazio e scansione del tempo. Studio della composizione narrativa del rilievo assiro di VII secolo a.C. (Contributi e materiali di archeologia orientale CMAO 12). Roma: Università La Sapienza, Dipartimento di scienze storiche, archeologiche ed antropologiche dell'antichità, 2006.

NADALI, Davide. The role of the image of the king in the organizational and compositional principles of Sennacherib's throne room: a guide to the historical narrative and meaning of a specified message. In: KÜHNE, Hartmut; CZICHON, Rainer M.; KREPPNER, Florian J. (orgs.). Proceedings of the $4^{\text {th }}$ International Congress of the Archeology of the Ancient Near East, Berlin, mar./abr. 2004. v. 1. Wiesbaden: Harrassowitz Verlag: 2008, p. 473-493.

NADALI, Davide. An urban perspective of Nineveh. Mesopotamia, v. L, p. 157-176, 2015.

NADALI, Davide. Community and individuals: how memory affects public and private life in the ancient Near East. In: NADALI, Davide (org.). Envisioning the past through memories. How memory shaped ancient Near Eastern societies. London: Bloomsbury, 2016, p. 37-52.

NADALI, Davide. The doubling of the image of the king: a note on Slabs B-13 and B-23 in the Throne Room of Assurnasirpal II at Nimrud. In: D'Andrea, Marta et al. (orgs.). Pearls of the past. studies on Near Eastern art and archaeology in honour of Frances Pinnock. Münster: Zaphon, 2019a, p. 661-675.

NADALI, Davide. Bas-reliefs as a source for Neo-Assyrian History. In: LANFRANCHI, Giovanni B.; MATTILA, Rajia; ROLLINGER, Robert (orgs.). Writing Neo-Assyrian History: sources, problems, and approaches. Helsinki: Neo-Assyrian Text Corpus Project, 2019b, p. 329-339.

NADALI, Davide. How ancient and modern memory shapes the past. A canon of Assyrian memory. In: GANSELL, Amy R.; SHAFER, Ann (orgs.). Testing the canon of ancient Near Eastern art and archaeology. Oxford: Oxford University Press, 2020, p. 217-231.

PORTUESE, Ludovico. The Throne Room of Aššurnașirpal II: a multisensory experience. In: RENDU LOISEL, Anne-Caroline; HAWTHORN, Ainsley (orgs.). Distant impressions. The senses in the ancient Near East. Winona Lake, Penn: Eisenbrauns, 2019, p. 63-92. POZZER, Katia Maria P. Relação de poder no Império: arqueologia e iconografia da conquista de Lakiš. Maracanan, v. 9, n. 9, p. 10-30, 2013. Disponível em: https://www.e-publicacoes.uerj.br/index.php/maracanan/article/view/13513. Acesso em: 2 mai. 2021.

RADNER, Karen; ROBSON, Eleanor. Introduction. In: RADNER, Karen; ROBSON, Eleanor (orgs.). The Oxford Handbook of Cuneiform Culture. Oxford: Oxford University Press, 2011, p. xxvii-xxxii.

REDE, Marcelo. História e cultura material. In: CARDOSO, Ciro F.; VAINFAS, Ronaldo (orgs.). Novos domínios da história. Rio de Janeiro: Elsevier-Campus, 2012, p. 133-150.

REDE, Marcelo. Imagem da violência e violência da imagem. Guerra e ritual na Assíria (séculos IX-VII a.C.). Varia Historia, v. 34, n. 64, p. 591-623, 2018.

RICHARDSON, Seth. An Assyrian garden of ancestors: Room I, Northwest Palace, Kalhu. State Archives of Assyria Bulletin, v. 13, p. 145-216, 1999.

RUSSELL, John M. The program of the palace of Assurnasirpal II: issues in the research and presentation of Assyrian art. American Journal of Archaeology, v. 102, n. 4, p. 689-696, 1998.

RUSSELL, John M. Writing on the wall: studies in the architectural context of Late Assyrian palace inscriptions. Winona Lake, Penn: Eisenbrauns, 1999. 
STONE, Elizabeth C. The development of cities in ancient Mesopotamia. In: SASSON, Jack M. (org.). Civilizations of the ancient Near East. Massachusetts: Hendrickson Publishers, 2000, p. 235-248.

VERDERAME, Lorenzo. A glimpse into the activities of experts (ummânu) at the Assyrian royal court. In: GASPA, Salvatore et al. (orgs.). From source to History. Studies on ancient Near Eastern worlds and beyond. Dedicated to Giovanni Battista Lanfranchi on the occasion of his 65th birthday on June 23, 2014. Münster: Ugarit-Verlag, 2014. p. 713-728.

WINTER, Irene J. Royal Rhetoric and the development of historical narrative in Neo-Assyrian reliefs. Studies in visual communication, v. 7, p. 2-38, 1981. Disponível em: https:// repository.upenn.edu/svc/vol7/iss2/2/. Acesso em: 16 jun. 2020.

WINTER, Irene J. Le banquet royal assyrien: mise en œuvre de la rhetorique de l'abondance. In: GRANDJEAN, Catherine; HUGONIOT, Christophe; LION, Brigitte (orgs.). Le banquet du monarque dans le monde antique. Rennes; Tours: Presses Universitaires de Rennes; Presses Universitaires François-Rabelais, 2013, p. 287-309. 